\title{
Effect of ciglitazone on adipogenic transdifferentiation of bovine skeletal muscle satellite cells
}

\author{
Junfang Zhang ${ }^{1,2 \#}$, Qiang $\mathrm{Li}^{1,2 \#}$, Yan Yan ${ }^{1,2}$, Bin Sun ${ }^{1,2}$, Ying Wang ${ }^{1,2}$, Lin Tang ${ }^{1,2}$, \\ Enze Wang ${ }^{1,2}$, Jia Yu ${ }^{3}$, Kim Margarette Corpuz Nogoy ${ }^{3}$, Xiangzi $\mathrm{Li}^{1,2 *}$ and \\ Seong-Ho Choi ${ }^{3 *}$ \\ ${ }^{1}$ Engineering Research Center of North-East Cold Region Beef Cattle Science \& Technology \\ Innovation, Ministry of Education, Yanbian University, Yanji 133002, China \\ ${ }^{2}$ Department of Animal Science, Yanbian University, Yanji 133002, China \\ ${ }^{3}$ Department of Animal Science, Chungbuk National University, Cheongju 28644, Korea
}

Received: May 13, 2021

Revised: Jun 22, 2021

Accepted: Jun 30, 2021

\#These authors contributed equally to this work.

${ }^{*}$ Corresponding author

Xiangzi Li

Engineering Research Center of NorthEast Cold Region Beef Cattle Science \& Technology Innovation, Ministry of Education, Yanbian University, Yanji 133002, China.

Department of Animal Science, Yanbian University, Yanji 133002, China.

Tel: +86-433-243-5628

E-mail: Ixz@ybu.edu.cn

Seong-Ho Choi

Department of Animal Science,

Chungbuk National University,

Cheongju 28644, Korea.

Tel: +82-43-261-2545

E-mail: seongho@cbnu.ac.kr

Copyright $(\subset) 2021$ Korean Society of

Animal Sciences and Technology.

This is an Open Access article distributed under the terms of the

Creative Commons Attribution

Non-Commercial License (http:// creativecommons.org/licenses/by$\mathrm{nc} / 4.0 /$ ) which permits unrestricted non-commercial use, distribution, and reproduction in any medium, provided the original work is properly cited.

ORCID

Junfang Zhang

https://orcid.org/0000-0003-4856-2339

Qiang Li

https://orcid.org/0000-0003-2722-1324

\section{Abstract}

Ciglitazone is a member of the thiazolidinedione family, and specifically binds to peroxisome proliferator-activated receptor- $\gamma(P P A R \gamma)$, thereby promoting adipocyte differentiation. We hypothesized that ciglitazone as a PPARY ligand in the absence of an adipocyte differentiation cocktail would increase adiponectin and adipogenic gene expression in bovine satellite cells (BSC). Muscle-derived BSCs were isolated from six, 18-month-old Yanbian Yellow Cattle. The BSC were cultured for $96 \mathrm{~h}$ in differentiation medium containing $5 \mu \mathrm{M}$ ciglitazone (CL), $10 \mu \mathrm{M}$ ciglitazone (CM), or $20 \mu \mathrm{M}$ ciglitazone $(\mathrm{CH})$. Control (CON) BSC were cultured only in a differentiation medium (containing $2 \%$ horse serum). The presence of myogenin, desmin, and paired box 7 (Pax7) proteins was confirmed in the BSC by immunofluorescence staining. The $\mathrm{CL}, \mathrm{CM}$, and $\mathrm{CH}$ treatments produced higher concentrations of triacylglycerol and lipid droplet accumulation in myotubes than those of the CON treatment. Ciglitazone treatments significantly increased the relative expression of PPARY, CCAAT/enhancer-binding protein alpha (C/EBPa), C/EBP $\beta$, fatty acid synthase, stearoyl-CoA desaturase, and perilipin 2. Ciglitazone treatments increased gene expression of $P a x 3$ and $P a x 7$ and decreased expression of myogenic differentiation-1, myogenin, myogenic regulatory factor-5, and myogenin-4 ( $p<$ 0.01 ). Adiponectin concentration caused by ciglitazone treatments was significantly greater than CON $(p<0.01)$. RNA sequencing showed that 281 differentially expressed genes (DEGs) were found in the treatments of ciglitazone. DEGs gene ontology (GO) analysis showed that the top $10 \mathrm{GO}$ enrichment significantly changed the biological processes such as protein trimerization, negative regulation of cell proliferation, adipocytes differentiation, and cellular response to external stimulus. Kyoto Encyclopedia of Genes and Genomes pathway analysis showed that DEGs were involved in the p53 signaling pathway, PPAR signaling pathway, biosynthesis of amino acids, tumor necrosis factor signaling pathway, non-alcoholic fatty liver disease, PI3K-Akt signaling pathway, and Wnt signaling pathway. These results indicate that ciglitazone acts as PPARY agonist, effectively increases the adiponectin concentration and adipogenic gene expression, and stimulates the conversion of BSC to adipocyte-like cells in the absence of adipocyte differentiation cocktail.

Keywords: Bovine satellite cells, Ciglitazone, Adipogenesis, Myogenesis, Differentially expressed genes 
Yan Yan

https://orcid.org/0000-0001-9945-3509

Bin Sun

https://orcid.org/0000-0003-1768-6734

Ying Wang

https://orcid.org/0000-0002-5662-909X

Lin Tang

https://orcid.org/0000-0003-0276-8550

Enze Wang

https://orcid.org/0000-0002-3352-4885

Jia Yu

https://orcid.org/0000-0003-3035-0397

Kim Margarette Corpuz Nogoy

https://orcid.org/0000-0002-0958-7632

Xiangzi Li

https://orcid.org/0000-0003-3061-3847

Seong-Ho Choi

https://orcid.org/0000-0001-8869-0218

Competing interests

No potential conflict of interest relevant to

this article was reported.

\section{Funding sources}

This study was funded by the National Natural Science Foundation in China (Grant number 31660667) and the Research Fund of Engineering Research Center of NorthEast Cold Region Beef Cattle Science \& Technology Innovation, Ministry of Education and the "111" Project (D20034), China. This study also was supported by the National Research Foundation in Korea (grant number NRF-2018R1D1A3B07048219).

Acknowledgements

Not applicable.

Availability of data and material Upon reasonable request, the datasets of this study can be available from the corresponding author.

\section{Authors' contributions}

Conceptualization: Li X

Data curation: Sun B, Wang Y.

Formal analysis: Li Q.

Methodology: Zhang J, Li Q, Yan Y.

Software: Zhang J, Li Q, Yan Y.

Validation: Yu J, Nogoy KMC.

Investigation: Sun B, Wang Y, Tang L, Wang E.

Writing - original draft: Zhang J, Li Q.

Writing - review \& editing: Li X, Choi SH.

Ethics approval and consent to participate All experimental procedures involving animals were approved by the Institutional Animal Care and Use Committee of Yanbian University using the approval code YBU20160303.

\section{INTRODUCTION}

The thiazolidinediones (TZD) family specifically bind to and activate proliferator-activated receptor- $\gamma(P P A R \gamma)$, increase its expression and that of the related genes (e.g., CCAAT/ enhancer-binding protein alpha $[C / E B P \alpha])$, and promote adipocyte differentiation. Yeow et al. [1] demonstrated that the TZD rosiglitazone, in the absence of supplemental fatty acids, strongly up-regulated PPAR $\gamma$ expression in $\mathrm{C} 2 \mathrm{C} 12$ cells, and proposed that rosiglitazone inhibited myogenesis. Singh et al. [2] reported that the TZD ciglitazone up-regulated $P P A R \gamma$ and $C /$ $E B P \alpha$ gene expression and depressed myoblast fusion in porcine satellite cells. In our previous study, it was reported that bovine muscle satellite cells (BSC) cultured in a growth medium supplemented with oleic acid (18:1n-9) increases the PPAR $\gamma$ and $C / E B P \beta$ gene expressions in myotubes regardless of whether ciglitazone is added or not [3]. Teboul et al. [4] first reported the almost complete conversion of $\mathrm{C} 2 \mathrm{C} 12$ myoblasts to lipid-filled cells when incubated with linoleic acid (18:2n-6) plus the TZD pioglitazone, as indicated by a cessation of myoblast fusion, swelling of myoblasts through lipid filling, down-regulation of myogenin (MYOG), and up-regulation of adipocyte lipid-binding protein gene expression. In our previous study [3], we established that $10 \mu \mathrm{M}$ ciglitizone down-regulated the expression of genes associated with myogenesis, and upregulated genes involved in adipogenesis. However, we did not establish that $10 \mu \mathrm{M}$ ciglitizone would elicit maximal effects on adipogenesis and/or myogenesis. Therefore, we hypothesized that a greater concentration of ciglitazone would more strongly promote the adipocyte phenotype in bovine BSC. For the current study, we selected a differentiation medium containing Dulbecco's modified Eagle's medium (DMEM) supplemented with 2\% horse serum based on the study of Singh et al. [2], which described the transdifferentiation of porcine satellite cells into adipoblasts. Here, however, we altered the adipogenic mixture of that study such as the DMEM, horse serum, penicillin/streptomycin, ascorbic acid, biotin, acetic acid, pantothenic acid, dexamethasone, isobutyl ethylxanthine, insulin, and ciglitazone to include increasing concentrations of ciglitazone $(5,10$, and $20 \mu \mathrm{M})$. We changed the traditional cocktail of differentiation and studied the effect of ciglitazone alone on adipogenic transdifferentiation of BSC without other factors promoting lipid deposition. RNA-seq was used to further analyze and validate the changes of adipogenesis-related genes and pathways after treatment with different concentrations of ciglitazone. We added horse serum to the medium to promote BSC proliferation and myogenic gene expression to better reflect the in situ conditions.

\section{MATERIAL AND METHODS}

\section{Ethics statement}

All experimental procedures involving animals were approved by the Institutional Animal Care and Use Committee of Yanbian University using the approval code YBU-20160303.

\section{Isolation and culture of bovine satellite cells}

Using sterile techniques, the semimembranosus muscle was collected immediately after the slaughter of Yanbian yellow cattle. The connective tissues and visible fats were removed, and the muscle tissues were ground using a sterile meat grinder and incubated with $1 \%$ Pronase (10165921001, Roche, Basel, Switzerland) in EBSS (Sigma-Aldrich, Louis, MO, USA) solution at $37^{\circ} \mathrm{C}$ for $1 \mathrm{~h} \mathrm{[5].} \mathrm{Following} \mathrm{the} \mathrm{enzymatic} \mathrm{digestion} \mathrm{was} \mathrm{the} \mathrm{repeated} \mathrm{centrifugation} \mathrm{according}$ to the procedure previously published [3]. The obtained primary cells were suspended in DMEM (Gibco, Thermo Fisher Scientific, Waltham, MA, USA) containing 10\% fetal bovine serum (FBS) 
(Gibco, Thermo Fisher Scientific) and 10\% (vol/vol) dimethyl sulfoxide (Sigma-Aldrich), frozen, and stored in liquid nitrogen for subsequent experiments. The BSCs were cultured in DMEM containing $10 \% \mathrm{FBS}$, and $1 \times$ antibiotic-antimycotic (Gibco) in a humidified incubator at $37^{\circ} \mathrm{C}$ with $5 \% \mathrm{CO}_{2}$. The growth medium was replaced with a differentiation medium after the cells have reached $80 \%$ confluence. The differentiation medium of Singh et al. [2] was followed omitting the insulin, pantothenic acid, and dexamethasone, and supplemented with $5 \mu \mathrm{M}$ ciglitazone (dissolved in ethanol, Sigma-Aldrich) (CL), $10 \mu \mathrm{M}$ ciglitazone (CM), or $20 \mu \mathrm{M}$ ciglitazone (CH). Each experiment was replicated in three independent cultures (passage no. 2 of the BSCs were used). The average cell size and viability were determined using the Luna automatic cell counter (Luna $I$, Logo Biosystems, Anyang, Korea).

\section{Immunostaining}

BSC were grown on $14 \mathrm{~mm}$ coverslip-bottomed dishes and fixed with $4 \%$ paraformaldehyde at ambient temperature for $20 \mathrm{~min}$, washed with phosphate buffered saline (PBS), permeabilized with $0.2 \%$ Triton X-100 (Sigma-Aldrich) at ambient temperature for $30 \mathrm{~min}$, and washed with PBS again. The polyclonal anti-myogenic differentiation 1 (MYOD1) (BS-2442R, Bioss, Beijing, China), anti-paired box 7 (Pax7) (AB-528428, Abcam, Cambridge, UK), and anti-desmin Po (BS20702R, Bioss) were diluted in PBS with 5\% bovine serum albumin (BSA) at a ratio of 1:100 and incubated at ambient temperature for $2 \mathrm{~h}$. The horseradish peroxidase (HRP)-labeled Goat AntiMouse Immunoglobulin G (IgG) (H + L) (A0216, Beyotime, Shanghai, China) or Goat AntiRabbit IgG-HRP antibody (BS-3550R, Bioss) was diluted in PBS with 5\% BSA at a ratio of 1:200 and incubated for $2 \mathrm{~h}$ at ambient temperature in the dark. Finally, the BSC was incubated in the $0.1 \mu \mathrm{g} / \mathrm{mL}$ 4',6-diamidino-2-phenylindole, dihydrochloride solution for $30 \mathrm{~min}$ in the dark and observed with a fluorescence microscope (WF10X, Olympus, Tokyo, Japan).

\section{Oil red $\mathrm{O}$ staining and lipid droplet area quantification}

To evaluate the transdifferentiation BSCs, after $96 \mathrm{~h}$ of differentiation, the cells were fixed with Oil Red O (ORO) Fixative for 30 min and stained with hematoxylin staining solution for $2 \mathrm{~min}$ at ambient temperature. The staining protocol was performed according to the instructions provided by the ORO staining kit (G1262, Solarbio, Beijing, China). Images were collected using an inverted microscope (IX-73, Olympus) and 20 different stained areas were captured. Image analysis followed the protocol of Deutsch et al. [6] using the ImageJ software 1.43u (http://rsbweb.nih.gov/ij). The average lipid droplet size was evaluated using GraphPad Prism 6.07.

\section{Quantitative triacylglycerol assay}

The concentration of triacylglycerol (TAG) was measured using the TAG Quantitative Assay Kit (Applygen, Beijing, China) according to the manufacturer's instructions. After $96 \mathrm{~h}$ of differentiation, the BSC was washed with PBS to remove the medium, and the cells were lysed with Radio-ImmunoPrecipitation Assay lysis solution at ambient temperature for $10 \mathrm{~min}$. Lipase is used to decompose TAG in cell lipid droplets to release glycerol, and the glycerol release amount is measured by spectrophotometric detection at $570 \mathrm{~nm}$.

\section{RNA extraction and real-time polymerase chain reaction}

After BSC was induced to differentiate in vitro for $96 \mathrm{~h}$, total RNA was extracted from cells using Trizol reagent (Thermo Fisher Scientific). The integrity (quantity and quality) of the extracted total RNA was quantified using a NanoDrop ND-100 spectrophotometer (2000C, Thermo Fisher Scientific), and the purity values (A260 / A280) of all RNA samples were greater than 1.80 
and were further verified by $1 \%$ agarose gel. The RNA samples of good quality were selected for further reverse transcription. Total RNA of $1 \mu \mathrm{g}$ was reverse-transcribed into cDNA using the FastKing one-step kit (Tiangen Biotech, Beijing, China). Real-time polymerase chain reaction (RT-PCR) was performed using the SYBR premix SuperReal PreMix Plus Kit (SYBRGreen, Tiangen Biotech) and thermocycler Agilent Mx3000/5p system (Agilent Mx3000/5p, Agilent Technologies, Santa Clara, CA, USA). The glyceraldehyde-3-phosphate dehydrogenase gene was used as the housekeeping gene. The genes Pax3, Pax7, MyoD1, and MyoG were selected as myogenic specific marker genes to characterize the extent of myogenesis, while the genes PPAR $\gamma$, $\mathrm{C} / \mathrm{EBP} \alpha, \mathrm{C} / \mathrm{EBP} \beta$, sterol regulatory element-binding protein (SREBP)1, stearoyl-coenzyme A desaturase (SCD), carnitine palmitoyltransferase (CPT1), adenosine 5'-monophosphate-activated protein kinase (AMPK $\alpha$ ), lipoprotein lipase (LPL), G protein-coupled receptor-43 (GPR43), perilipin-2 (PLIN2), and fatty acid binding protein-4 (FABP4) were used to characterize the degree of adipogenic/lipogenic gene expression. The sequences of the primers are given in Table 1. The thermocycling conditions were as follows: preheating at $95^{\circ} \mathrm{C}$ for $15 \mathrm{~min}$, a total of 45 cycles of denaturation at $95^{\circ} \mathrm{C}$ for $10 \mathrm{~s}$, annealing temperature at $60^{\circ} \mathrm{C}$ for $30 \mathrm{~s}$ and extension temperature at $72^{\circ} \mathrm{C}$ for $32 \mathrm{~s}$ with a melting curve from $65^{\circ} \mathrm{C}$ to $95^{\circ} \mathrm{C}$. The quantitative $\mathrm{PCR}$ results were calculated using the $2^{-\Delta \Delta \mathrm{Ct}}$ method to determine the relative mRNA expression levels.

\section{Adiponectin in bovine satellite cell culture media}

After BSC differentiation culture for $96 \mathrm{~h}$, the content of adiponectin in the differentiation medium was analyzed using the bovine adiponectin ADP kit (Mlbio, Shanghai, China). The absorbance (OD value) was measured with a microplate reader (BIO-RAD, Hercules, CA, USA) at a wavelength of $450 \mathrm{~nm}$, and the concentration of bovine adiponectin in the sample was calculated from the standard curve.

\section{Construction of RNA-seq library, quality control, and sequencing}

After $96 \mathrm{~h}$ of BSC differentiation, total RNA was extracted from each treatment using TRIzol ${ }^{\mathrm{TM}}$ Reagent (Invitrogen, Waltham, MA, USA) according to the manufacturer's instructions. The isolated RNA was cleared of contaminating genomic DNA by DNase treatment (Thermo Fisher Scientific). Prior to Illumina RNA sequencing, 1\% nondenaturing agarose gel electrophoresis and a Nano-Photometer ${ }^{\circledR}$ spectrophotometer (IMPLEN, Munich, Germany) were used to assess the quality and quantity of the isolated RNA, respectively. Samples satisfying the criteria of RNA integrity number $>7$ were utilized for the following library preparation. RNA purification, reverse transcription, library construction, and sequencing were completed by AMOGENE. Briefly, the mRNA was enriched by oligo (dT) beads and was fragmented into short fragments through fragmentation buffer at $94^{\circ} \mathrm{C}$ for $5 \mathrm{~min}$. First-strand cDNA was synthesized by a random hexamer primer (Illumina) and M-MuLV Reverse Transcriptase (Invitrogen), using the short fragments as templates, at the condition of $25^{\circ} \mathrm{C}$ for $10 \mathrm{~min}$, followed by $42^{\circ} \mathrm{C}$ for $50 \mathrm{~min}$ for synthesis and $70^{\circ} \mathrm{C}$ for $15 \mathrm{~min}$ for RTase inactivation. Second strand cDNA synthesis was subsequently performed using Second Strand Master Mix (Illumina) at $16^{\circ} \mathrm{C}$ for $1 \mathrm{~h}$. Next, the cDNA fragments of 150-200 bp in length were treated with T4 DNA polymerase and 5' phosphorylated, and then an adenine (A) residue was added to the $3^{\prime}$ ends of the DNA. Moreover, adapters were also ligated to the ends of these target template DNAs. After ligation, the cDNA library was obtained by PCR amplification (5-9 cycles). Finally, PCR products were purified, and library quality was evaluated on an Agilent. Bioanalyzer 2100 system (Agilent Technologies). The library preparations were sequenced on an Illumina Hiseq 4000 platform using paired-end technology following the manufacturer's standard guidelines. Fastp was used to filter the original sequencing data to obtain 
Table 1. Forward and reverse primers for Real-time polymerase chain reaction

\begin{tabular}{|c|c|c|c|}
\hline Genes & Accession no. & & Primer Sequence (5'-3') \\
\hline \multirow[t]{2}{*}{ Pax3 } & NSO_4856884_001 & Forward: & GGCTGCGTCTCTAAGATCCT \\
\hline & & Reverse: & ATTTCCCAGCTGAACATGCC \\
\hline \multirow[t]{2}{*}{ Pax7 } & NSO_4856884_004 & Forward: & TGCCCTCAGTGAGTTCGATT \\
\hline & & Reverse: & CGGGTTCTGACTCCACATCT \\
\hline \multirow[t]{2}{*}{ MYOD } & 8404456555 & Forward: & CCGACGGCATGATGGACTA \\
\hline & & Reverse: & CTCGCTGTAGTAAGTGCGGT \\
\hline \multirow[t]{2}{*}{ MYOG } & 8404456557 & Forward: & CAGTGAATGCAGCTCCCATAG \\
\hline & & Reverse: & GCAGATGATCCCCTGGGTTG \\
\hline \multirow[t]{2}{*}{ MYF4 } & 8404456562 & Forward: & TGGACCCCTTCAGCTACAGA \\
\hline & & Reverse: & АTGCTTGTCССТССTTCCTTG \\
\hline \multirow[t]{2}{*}{ MRF5 } & 8404456560 & Forward: & СССАССТСААGTTGСТСТGА \\
\hline & & Reverse: & CCGTGGCATATACATTTGGTACA \\
\hline \multirow[t]{2}{*}{ PPARY } & NSE_1498162_016 & Forward: & ATCTGCTGCAAGCCTTGGA \\
\hline & & Reverse: & TGGAGCAGCTTGGCAAAGA \\
\hline \multirow[t]{2}{*}{ C/EBPß } & 840057464 & Forward: & CCAGAAGAAGGTGGAGCAACTG \\
\hline & & Reverse: & TCGGGCAGCGTCTTGAAC \\
\hline \multirow[t]{2}{*}{ SREBP1 } & NSE_1498162_022 & Forward: & CACCGAGGCCAAGTTGAATAA \\
\hline & & Reverse: & CCAGGTCCTTCAGCGATTTG \\
\hline \multirow[t]{2}{*}{$\mathrm{C} / \mathrm{EBPa}$} & NSO_5140066_004 & Forward: & ATCGACATCAGCGCCTACAT \\
\hline & & Reverse: & GCCCGGGTAGTCAAAGTCG \\
\hline \multirow[t]{2}{*}{ ACC } & 8405780950 & Forward: & СТССААССТСААССАСТАCGG \\
\hline & & Reverse: & GGGGAATCACAGAAGCAGCC \\
\hline \multirow[t]{2}{*}{ FAS } & 8405780945 & Forward: & TAAGGTTCAAATTGCTGCGT \\
\hline & & Reverse: & TCCAGAGCGAAGGAGAGATT \\
\hline \multirow[t]{2}{*}{ CPT1 } & 84044456553 & Forward: & АCACATCTACCTGTCCGTGATCA \\
\hline & & Reverse: & CCСCTGAGGATGCCATTCT \\
\hline \multirow[t]{2}{*}{ SCD } & NSE_1498162_019 & Forward: & TGCCCACCACAAGTTTTCAG \\
\hline & & Reverse: & GCCAACCCACGTGAGAGAAG \\
\hline \multirow[t]{2}{*}{ AMPKa } & 8404456568 & Forward: & CACCAAGGTGTAAGGAAAGCA \\
\hline & & Reverse: & ACGGGTTTACAACCTTCCATTC \\
\hline \multirow[t]{2}{*}{ LPL } & NSE_1498162_015 & Forward: & ACGATTATTGCTCAGCATGG \\
\hline & & Reverse: & ACTTTGTACAGGCACAACCG \\
\hline \multirow[t]{2}{*}{ GPR43 } & NSO_5189193 & Forward: & GGCTTTCCCCGTGCAGTA \\
\hline & & Reverse: & ATCAGAGCAGCGATCACTCCAT \\
\hline \multirow[t]{2}{*}{ FABP4 } & AJ_4160220 & Forward: & AAACTTAGATGAAGGTGCTCTGG \\
\hline & & Reverse: & CATAAACTCTGGTGGCAGTGA \\
\hline \multirow[t]{2}{*}{ PLIN2 } & NSO_5379931 & Forward: & GCGTCTGCTGGCTGATTTCT \\
\hline & & Reverse: & TGTAAGCCGAGGAGACCAGA \\
\hline \multirow[t]{2}{*}{ GAPDH } & NSO_4761240 & Forward: & ACTCTGGCAAAGTGGATGTTGTC \\
\hline & & Reverse: & GCATCACCCCACTTGATGTTG \\
\hline
\end{tabular}

Pax3, paired box 3; Pax7, paired box 7; MYOD, myogenic differentiation-1; MYOG, myogenin; MYF4, myogenin-4; MRF5, myogenic regulatory factor-5; PPARY, peroxisome proliferator-activated receptor gamma; C/EBPß, CCAAT/enhancer-binding protein beta; SREBP1, sterol regulatory element-binding protein-1; C/EBPa, CCAAT/enhancer-binding protein alpha; ACC, acetyl-coenzyme A carboxylase; FAS, fatty acid synthetase; CPT1, carnitine palmitoyltransferase; SCD, stearoyl-coenzyme A desaturase; AMPKa, adenosine 5'-monophosphate-activated protein kinase; LPL, lipoprotein lipase; GPR43, G protein-coupled receptor-43; FABP4, fatty acid binding protein-4; PLIN2, perilipin-2; GAPDH, glyceraldehyde-3-phosphate dehydrogenase. 
clean data, and the filtered data were evaluated with the RSeQC software package to obtain highquality sequencing data, and then Spliced Transcripts Alignments to a Reference software was used for sequence alignment analysis with the reference genome.

\section{Differentially expressed genes identification}

Cuffdiff was used to assemble the RNA-Seq alignments and estimate gene expression and transcript. The edgeR package was used for the identification of differentially expressed genes (DEGs) within samples. Genes with statistical significance were retained first (q-value < 0.05); significant DEGs were compared with a fold change of $>1.5$ than 1.5 or $<0.667$ were retained $[\log 2(1.5)=0.5849 ; \log 2(0.667)=-0.5849]$.

\section{Functional enrichment analysis}

The DEGs were subjected to the Kyoto Encyclopedia of Genes and Genomes (KEGG) pathway and enrichment analysis of Gene Ontology (GO). KEGG enrichment analysis was to identify the pathways of significant enrichment of DEGs, gene function, genomic information, and functional information. The GO classification includes the following three aspects: biological process (BP), molecular function $(\mathrm{MF})$, and cellular component $(\mathrm{CC})$, which define and describe the functions of selected genes and corresponding proteins. KEGG was separately generated by (http://www. genome.jp/kegg).

\section{Statistical analysis}

One-way ANOVA with multiple comparisons test was used to evaluate the statistical significance of differences among treatments. All data are presented as mean \pm SEM. The graphs were prepared using GraphPad Prism 6.07 (GraphPad, San Diego, CA, USA). Statistical significance was set at $p$ $<0.05$.

\section{RESULTS}

Identification of skeletal muscle satellite cells

MyoD1 antibodies, Desmin, and Pax7 antibodies were used to monitor myogenic differentiation of BSC, which has been characterized by immunofluorescence staining of proliferation positive BSC (Fig. 1).

\section{Average cell size and cell viability}

A total of $1,125 \pm 7.82$ cells were analyzed for each treatment to measure the average cell size. There was no significant difference in cell size $(p=0.57)$ and cell vitality between treatments $(p=0.47)$ (Fig. 2).

\section{BSC differentiation and lipid accumulation}

Control BSC proliferated and fuse to form myotubes. Upon incubation of BSC with ciglitazone, the cells became adipocyte-like cells, and the effect is obvious after $96 \mathrm{~h}$ (Fig. 3). Increasing the concentration of ciglitazone greatly accelerated the appearance of adipocyte-like cells, and strongly increased the number of BSC that differentiated into adipocytes. Exposure of post-confluent cells to the differentiation medium plus ciglitazone decreased myotube formation, with a concomitant increase in the area of cells containing lipid droplets and the formation of adipocytes. 
A
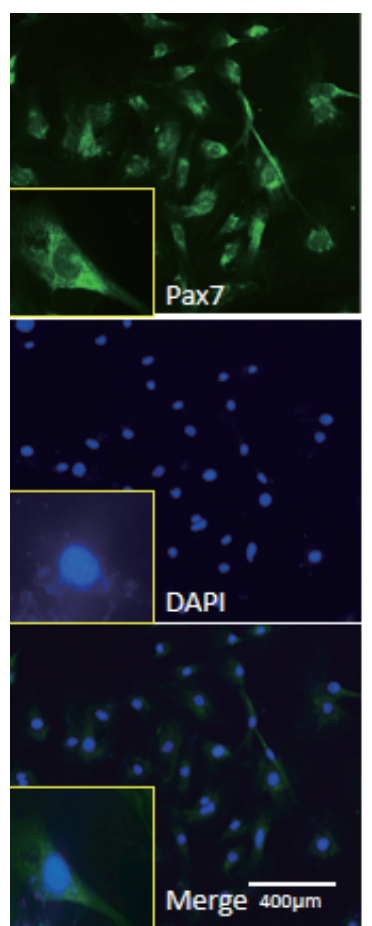

B
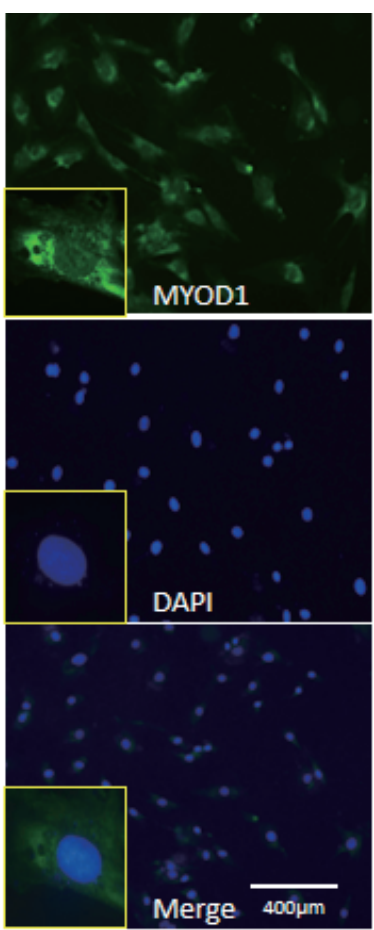

C
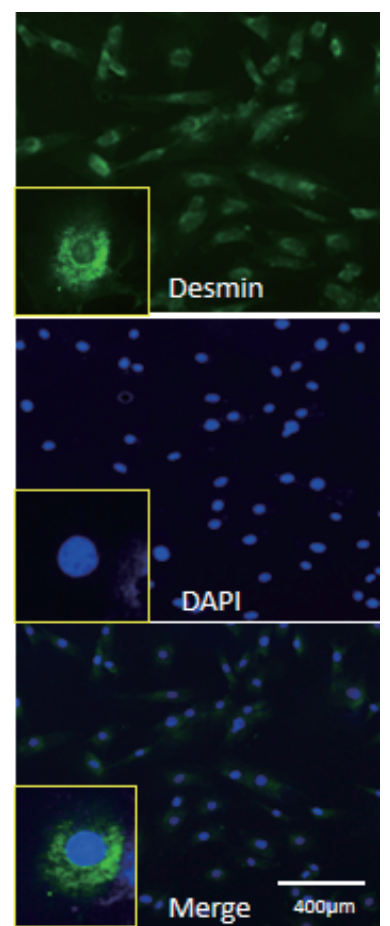

Fig. 1. Immunofluorescence. The nucleus after DAPI staining was blue, and Pax7 (A), MYOD1 (B) and Desmin (C) were green in the cytoplasm. The original magnification was $40 \times$ (scale bars $=200 \mu \mathrm{m}$ ). Results represent three independent experiments. Pax7, Paired box 7; DAPI, 4',6-Diamidino-2-Phenylindole, dihydrochloride.
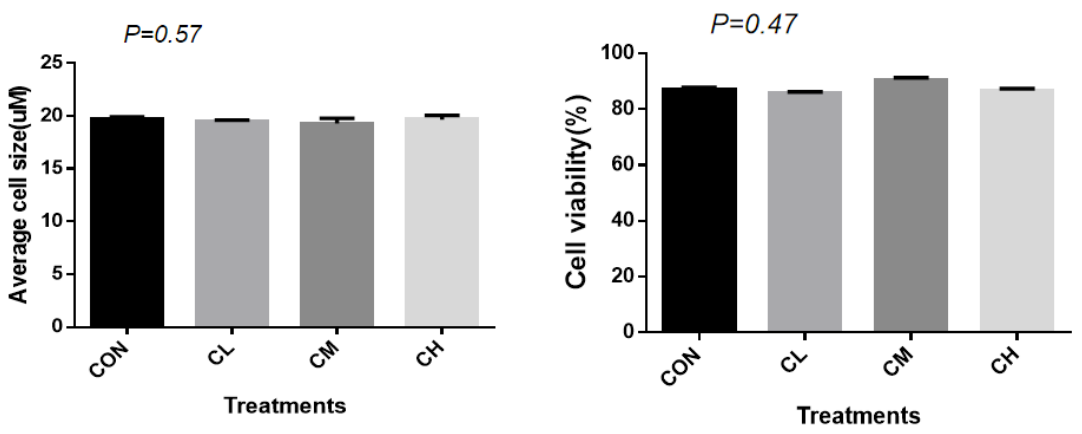

Fig. 2. Effects of different concentrations of ciglitazone on average cell size and cell viability in BSC after $96-\mathrm{h}$ culture. CON, DMEM + $2 \% \mathrm{HS}$; CL, CON $+5 \mu \mathrm{M}$ ciglitazone; $\mathrm{CM}, \mathrm{CON}+10 \mu \mathrm{M}$ ciglitazone; $\mathrm{CH}$, $\mathrm{CON}+20 \mu \mathrm{M}$ ciglitazone. The same superscript or no superscript on the column means that the difference is not significant $(p>0.05)$. BSC, bovine satellite cells; DMEM, Dulbecco's modified Eagle's medium; HS, horse serum.

\section{Triacylglycerol and lipid droplet area quantification}

The concentration of cellular TAG, the main component of lipid droplets, was elevated linearly by $\mathrm{CL}, \mathrm{CM}$, and $\mathrm{CH}$ treatments and, correspondingly, CL, CM, and $\mathrm{CH}$ treatments caused a profound increase in the percent area of lipid droplets (Fig. 4$)(p<0.01)$.

\section{Myogenic gene expression}

The CL, CM, and $\mathrm{CH}$ treatments increased Pax3 and Pax7 expression and decreased MYOD, 
A

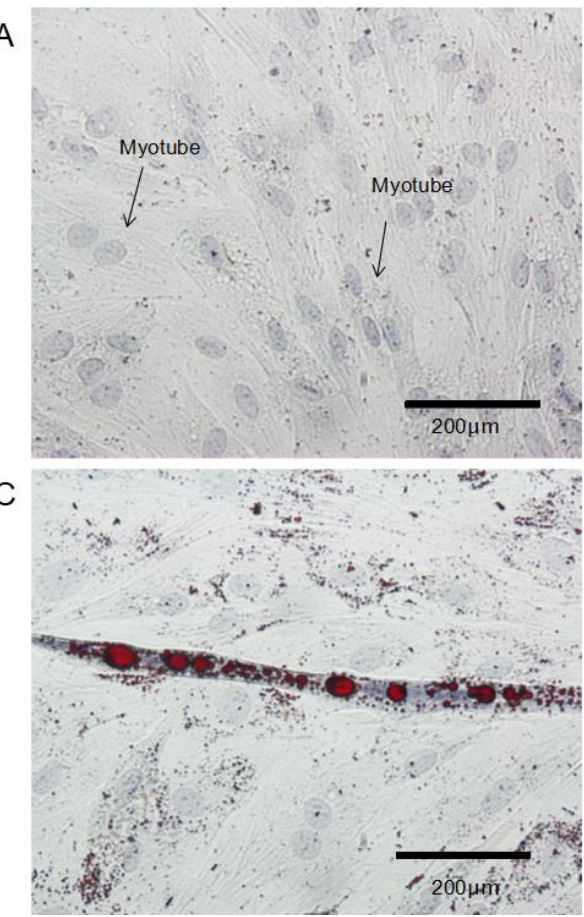

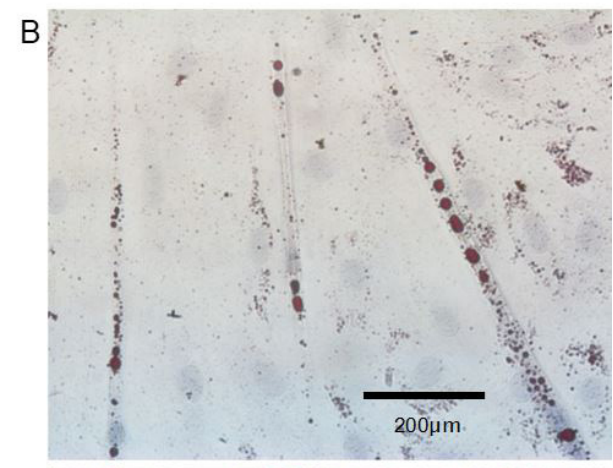

D

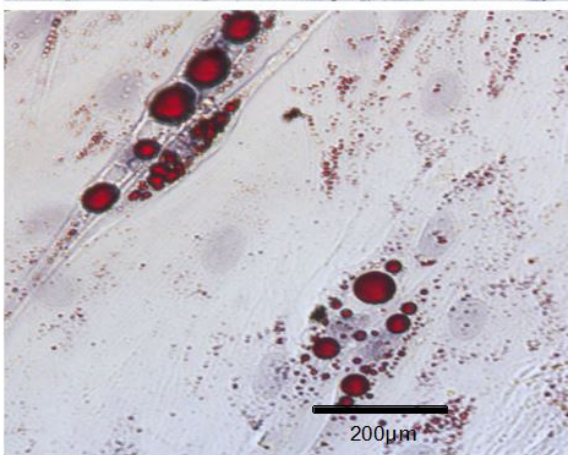

Fig. 3. Oil red $\mathrm{O}$ staining after $96-\mathrm{h}$ incubation of BSC treated with ciglitazone. (A) CON (DMEM $+2 \%$ horse serum), (B) $\mathrm{CL}$ (CON $+5 \mu \mathrm{M}$ ciglitazone), (C) $\mathrm{CM}$ (CON + $10 \mu \mathrm{M}$ ciglitazone), (D) $\mathrm{CH}$ (CON + $20 \mu \mathrm{M}$ ciglitazone). Scale bars $=200 \mu \mathrm{m}$. BSC, bovine satellite cells; DMEM, Dulbecco's modified Eagle's medium.
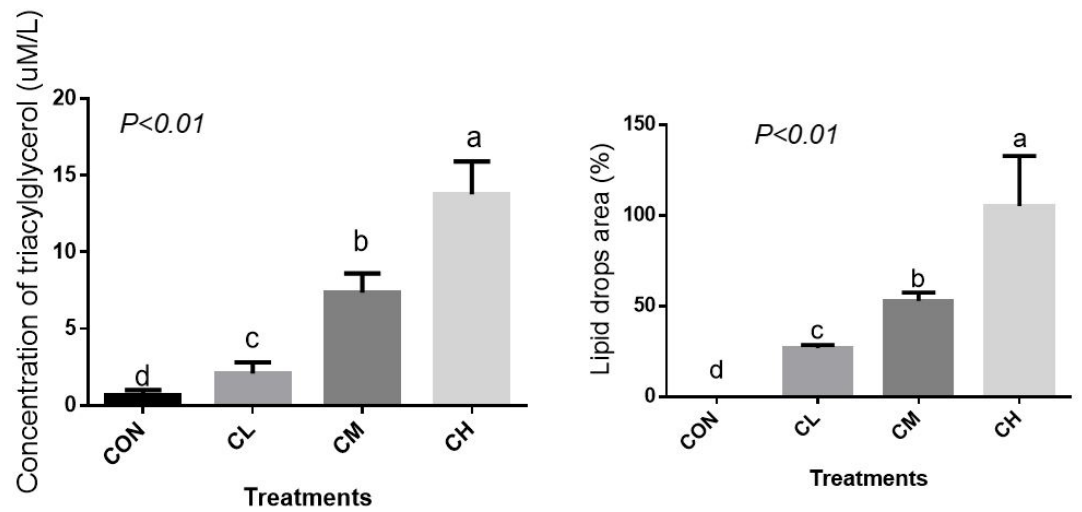

Fig. 4. Effect of ciglitazone on triacylglycerol and percent lipid droplet area in BSC after $96 \mathrm{~h}$ of culture. $\mathrm{CON}, \mathrm{DMEM}+2 \% \mathrm{HS} ; \mathrm{CL}, \mathrm{CON}+5 \mu \mathrm{M}$ ciglitazone; $\mathrm{CM}, \mathrm{CON}+10 \mu \mathrm{M}$ ciglitazone; $\mathrm{CH}, \mathrm{CON}+20 \mu \mathrm{M}$ ciglitazone. Error bars are mean $\pm \mathrm{SE} .{ }^{\mathrm{a}-\mathrm{d}}$ Indicate a significant difference $(p<0.01)$ within an item compared with undifferentiated cells. The results are representative of six independent experiments. BSC, bovine satellite cells; DMEM, Dulbecco's modified Eagle's medium; HS, horse serum.

MYOG, myogenin-4 (MYF4), and myogenic regulatory factor-5 (MRF5) expression relative to CON $(p<0.01)$ (Fig. 5). The expression of MYF4 and MRF5 were the least in the $\mathrm{CH}$-treated $\mathrm{BSC}(p<$ $0.01)$.

\section{Associated with adipogenic and lipid metabolism}

There was a dose-response to ciglitazone addition for the expression of adipogenic transcription factors $P P A R \gamma, S R E B P 1, C / E B P \alpha, C / E B P \beta$, acetyl-coenzyme A carboxylase, and fatty acid 
$\operatorname{Pax} 3$
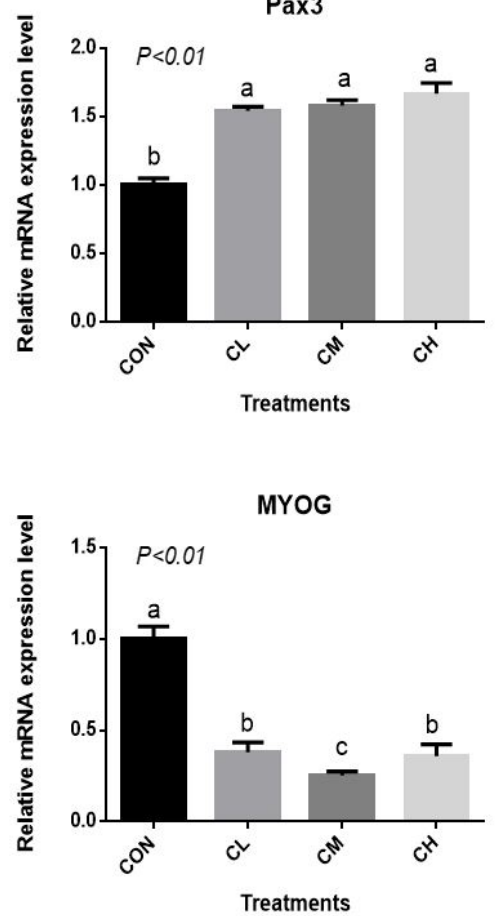

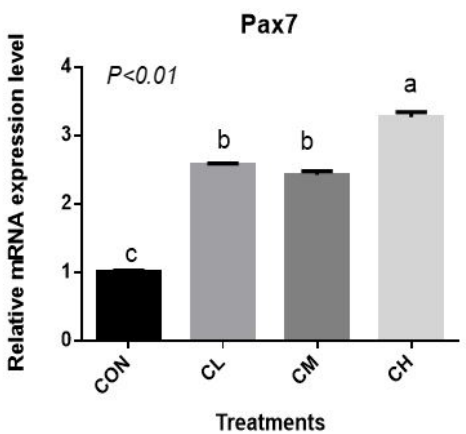

MYF4

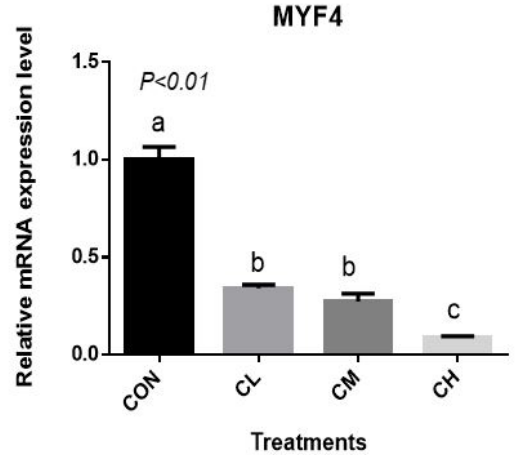

MyoD

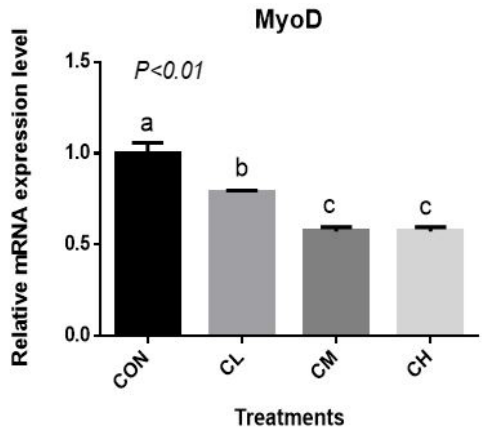

MRF5

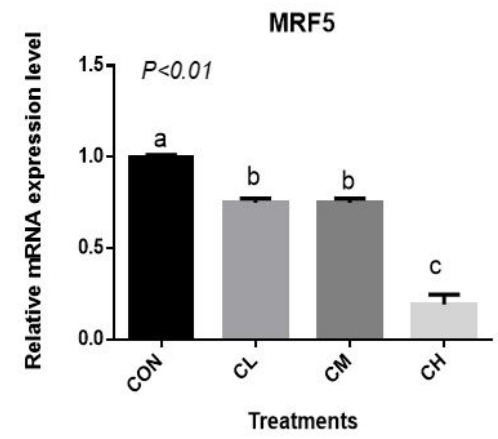

Fig. 5. Myogenic gene expression: Pax3, Pax7, MYOD, MYOG, MYF4, and MRF5 gene expression in BSC cultured with ciglitazone in DMEM containing $2 \% \mathrm{HS}$ after $96 \mathrm{~h}$ of incubation. CON, DMEM $+2 \% \mathrm{HS} ; \mathrm{CL}, \mathrm{CON}+5 \mu \mathrm{M}$ ciglitazone; $\mathrm{CM}, \mathrm{CON}+10 \mu \mathrm{M}$ ciglitazone; $\mathrm{CH}, \mathrm{CON}+20 \mu \mathrm{M}$ ciglitazone. The results of gene expression were consistent with protein expression. The bars are the means \pm SE. ${ }^{a-d}$ Indicate a significant difference $(p<0.01)$ within an item compared with undifferentiated cells. The results are representative of six independent experiments. Pax3, Paired box 3; Pax7, Paired box 7; MYOD, myogenic differentiation-1; MYOG, myogenin; MYF4, myogenin-4; MRF5, myogenic regulatory factor-5; BSC, bovine satellite cells; DMEM, Dulbecco's modified Eagle's medium; HS, horse serum.

synthetase $(p<0.01)$, and the greatest increase in the expression of these genes, were caused by $\mathrm{CH}-$ treated BSC (Fig. 6). Relative expression of SCD, LPL, GPR43, FABP4, and PLIN2 was dosedependent as the addition level of ciglitazone increased $(p<0.01)$ (Fig. 7). Expression of CPT1 was depressed by the CL, CM, and CH-treated BSC stepwise relative to CON BSC. Expression of $A M P K \alpha(p<0.01)$ was greater in CL, CM, and CH-treated BSC than in CON BSC, and the $\mathrm{CM}$ treatment caused the greatest increase.

\section{Culture media adiponectin}

Compared with CON BSC, the CL, CM, and $\mathrm{CH}$ treatments increased the amount of adiponectin $(A D P)$ secretion $(p<0.01)$, and the highest concentration of $A D P$ was caused by the $\mathrm{CH}$ treatment (Fig. 8).

\section{Analysis of differentially expressed genes in bovine satellite cell}

Whole-genome expression profiling with RNA-Sequencing analysis revealed significant DEGs when the BSC were treated with different levels of ciglitazone. Compared with CON, the CL treatment up-regulated 611 genes and down-regulated 510 genes; the $\mathrm{CM}$ treatment up-regulated 565 genes and down-regulated 527 genes; whereas the $\mathrm{CH}$ treatment up-regulated 501 genes and down-regulated 435 genes (Table 2). Combined with the analysis of these results of differential expressed genes, BSC treated with CL, CM, and CH had 281 DEGs as shown in the volcano map (Fig. 9A, B, and C). 

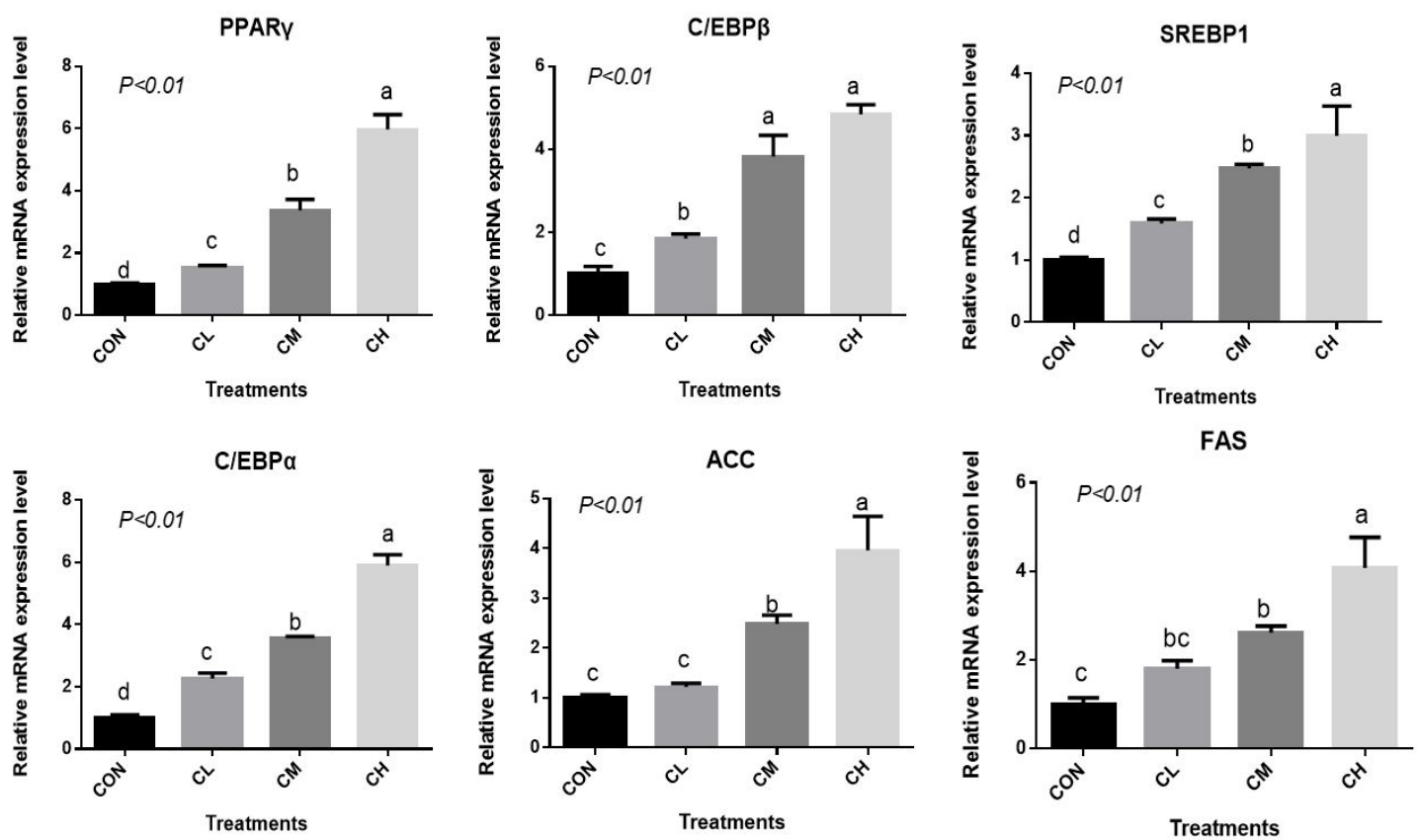

Fig. 6. Adipogenic gene expression: PPARy, C/EBP $\beta$, SREBP1, C/EBPa, ACC, FAS gene expression in BSC cultured with ciglitazone in DMEM containing $2 \% \mathrm{HS}$ after $96 \mathrm{~h}$ of incubation. CON, DMEM $+2 \% \mathrm{HS} ; \mathrm{CL}, \mathrm{CON}+5 \mu \mathrm{M}$ ciglitazone; $\mathrm{CM}, \mathrm{CON}+10 \mu \mathrm{M}$ ciglitazone; CH, CON $+20 \mu \mathrm{M}$ ciglitazone. The results of gene expression were consistent with protein expression. Error bars are the means $\pm \mathrm{SE} .{ }^{\mathrm{a}-\mathrm{d}}$ Indicate a significant difference $(p<$ 0.01 ) within an item compared with undifferentiated cells. The results are representative of six separate experiments. PPARy, peroxisome proliferator-activated receptor gamma; C/EBPß, CCAAT/enhancer-binding protein beta; SREBP1, sterol regulatory element-binding protein-1; C/EBPa, CCAAT/enhancer-binding protein alpha; ACC, acetyl-coenzyme A carboxylase; FAS, fatty acid synthetase; BSC, bovine satellite cells; DMEM, Dulbecco's modified Eagle's medium; HS, horse serum.

\section{Gene ontology analysis of differentially expressed gens in bovine satellite cell}

Pathway analysis of DEGs was performed to understand the biological relationship between pathways and molecules. The GO annotation was classified into three clusters: BP, MF, and CC. The 10 top significantly enriched GO terms in which the calculated by the hypergeometric test was $\mathrm{Q}<0.05$ were selected. As shown in Fig. 10 and (Supplementary Table S1, biological pathways were significantly changed by GO terms of ciglitazone-treated BSC. Top 10 GO enrichment analyses significantly changed cell proliferation, protein trimerization, fat cell differentiation, cellular response to external stimulus, positive regulation of release of cytochrome $\mathrm{c}$ from mitochondria, and type B pancreatic cell proliferation process. Molecular functions such as nuclease activity, endonuclease activity, deoxyribonuclease activity, growth factor activity, kinase inhibitor activity, biotinidase activity, and receptor-ligand activity were up-regulated by ciglitazone.

\section{Kyoto Encyclopedia of genes and genomes enrichment of differentially expressed genes in bovine satellite cell}

Pathway analysis of DEGs was conducted to understand the pathways and molecular interactions involved with ciglitazone treatment. The 10 top significantly enriched GO terms in which the calculated by the hypergeometric test was $\mathrm{Q}<0.05$ were selected. Enrichment degree was identified by Gene Ratio, P. adjust, and enriched genes. In the CL treated BSC, KEGG enrichment analysis indicated that a total of 465 DGEs were enriched in 31 pathways and mainly in glycine, serine, and threonine metabolism, tumor necrosis factor (TNF) signaling pathway, and the p53 signaling pathway. Genes with up-regulated expression were mainly enriched in mineral absorption, transcriptional misregulation in cancer, choline metabolism in cancer, glutathione metabolism. 

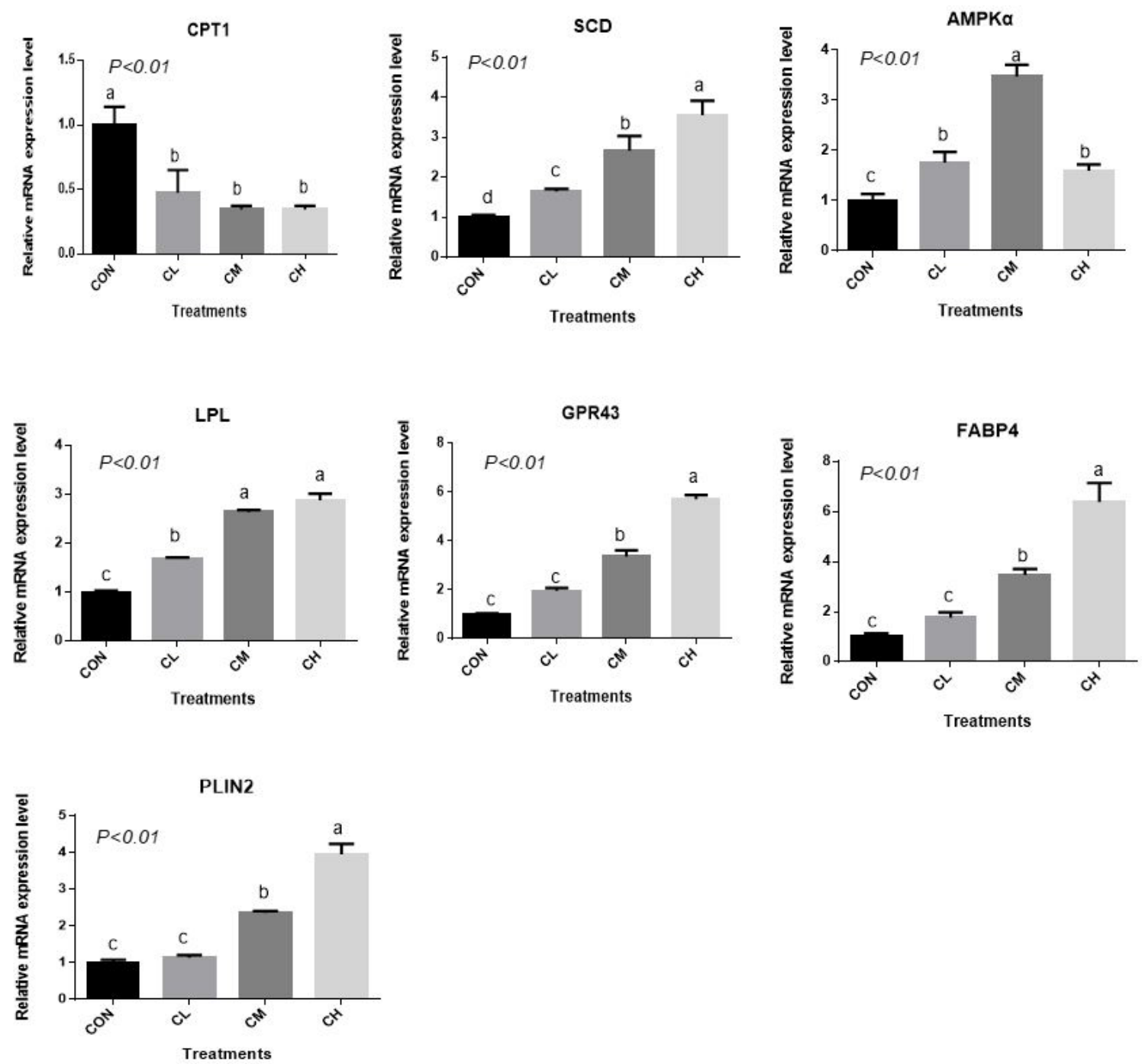

Fig. 7. Gene expression associated with lipid metabolism: CPT1, SCD, AMPKa, LPL, GPR43, FABP4, PLIN2 gene expression in BSC cultured with ciglitazone in DMEM containing $2 \% \mathrm{HS}$ at $96 \mathrm{~h}$ incubation time. CON, DMEM $+2 \% \mathrm{HS} ; \mathrm{CL}, \mathrm{CON}+5 \mu \mathrm{M}$ ciglitazone; $\mathrm{CM}, \mathrm{CON}+10 \mu \mathrm{M}$ ciglitazone; CH, $\mathrm{CON}+20 \mu \mathrm{M}$ ciglitazone. The results of gene expression were consistent with protein expression. The bars are the means $\pm \mathrm{SE} .{ }^{\mathrm{a}-\mathrm{d}}$ Indicate a significant difference $(p<0.01)$ within an item compared with undifferentiated cells. The results are representative of six independent experiments. CPT1, carnitine palmitoyltransferase; SCD, stearoyl-coenzyme A desaturase; AMPKa, adenosine 5'-monophosphate-activated protein kinase; LPL, lipoprotein lipase; GPR43, G protein-coupled receptor-43; FABP4, fatty acid binding protein-4; PLIN2, perilipin-2; BSC, bovine satellite cells; DMEM, Dulbecco's modified Eagle's medium; HS, horse serum.

Genes with down-regulated expression were mainly enriched in the TNF signaling pathway, biosynthesis of amino acids, protein digestion, and absorption.

In the CM treated BSC, a total of 484 DGEs were enriched in 18 pathways and mainly in apoptosis, p53 signaling pathway, non-alcoholic fatty liver disease (NAFLD), PI3K-Akt signaling pathway, Wnt signaling pathway, and TNF signaling pathway. Genes with up-regulated expression were mainly enriched in TNF signaling pathway, the calcium signaling pathway, apoptosis, RNA degradation, and genes with down-regulated expression were mainly enriched in the biosynthesis of amino acids, p53 signaling pathway, ribosome, carbon metabolism, and the PI3K-Akt signaling pathway. In the $\mathrm{CH}$ treated BSC, a total of 397 DGEs were enriched in 30 pathways and mainly in the p53 signaling pathway, PPAR signaling pathway, biosynthesis of amino acids, pentose phosphate pathway, and TGF-beta signaling pathway. Genes with up-regulated expression were 


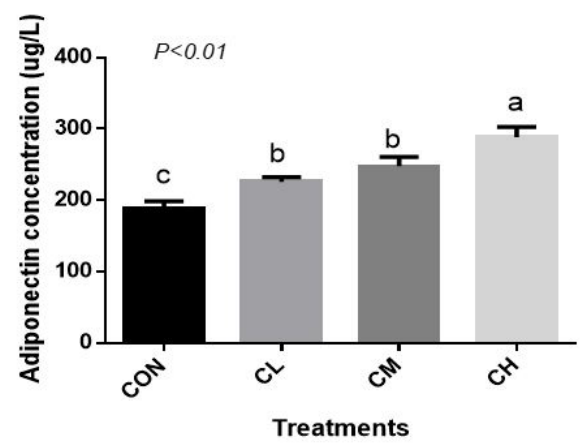

Fig. 8. Adiponectin concentration $(\mu \mathrm{g} / \mathrm{mL})$ in media from BSC cultured for $96 \mathrm{~h}$ with ciglitazone in DMEM containing $2 \% \mathrm{HS}$ at $96 \mathrm{~h}$ incubation time. CON, DMEM + 2\% HS; CL, CON + $5 \mu \mathrm{M}$ ciglitazone; CM, CON + $10 \mu \mathrm{M}$ ciglitazone; $\mathrm{CH}, \mathrm{CON}+20 \mu \mathrm{M}$ ciglitazone. The bars are the means $\pm \mathrm{SE} .{ }^{\mathrm{a}-\mathrm{d}}$ Indicate a significant difference $(p<0.01)$ within an item compared with undifferentiated cells. The results are representative of six independent experiments. BSC, bovine satellite cells; DMEM, Dulbecco's modified Eagle's medium; HS, horse serum.

Table 2. Number of DEGs after treatment with different concentrations of ciglitazone

\begin{tabular}{lccc}
\hline & Type & \multicolumn{3}{c}{ Treatment } \\
\cline { 2 - 4 } & CL & CM & CH \\
\hline Up & 609 & 562 & 501 \\
Down & 508 & 526 & 432 \\
Total & 1,117 & 1,088 & 933 \\
\hline
\end{tabular}

DEG, differentially expressed gene; $\mathrm{CL}$, ciglitazone; $\mathrm{CM}$, ciglitazone; $\mathrm{CH}$, ciglitazone.

A

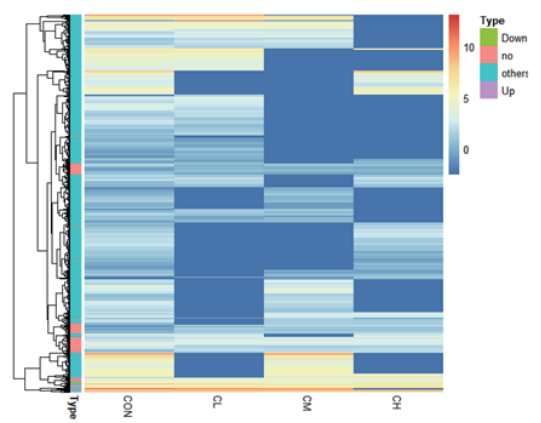

B

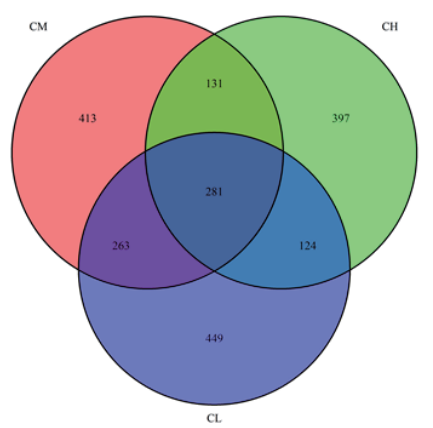

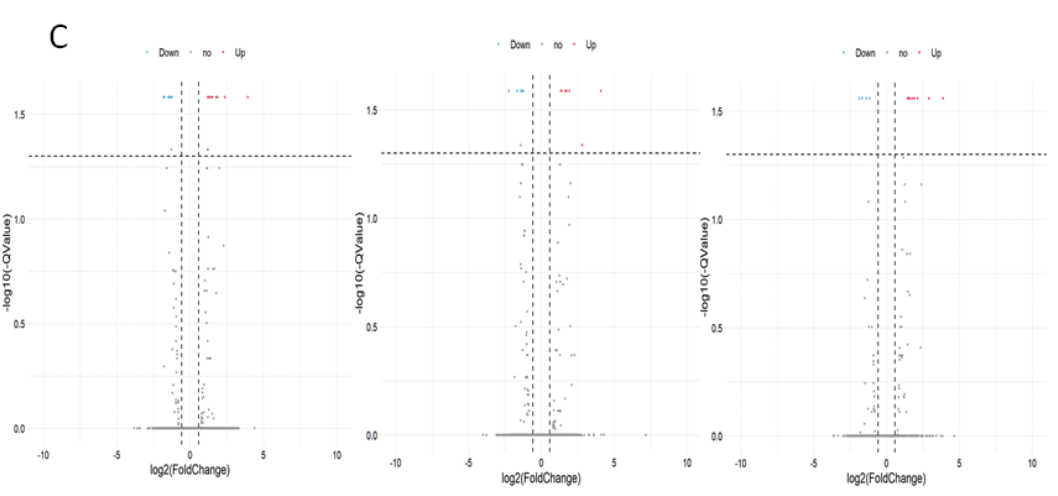

Fig. 9. Differentially Expressed Genes (DEGs) (A) Heatmap for the Figure hierarchical cluster analysis of DEGs after differentiation of BSC in Yanbian Yellow Cattle with different concentrations of ciglitazone, (B) Wayne map and (C) Volcano Plot. Red represents upregulated genes and blue represent downregulated genes. CON, DMEM + 2\%HS; CL, CON + $5 \mu \mathrm{M}$ ciglitazone; $\mathrm{CM}, \mathrm{CON}+10 \mu \mathrm{M}$ ciglitazone; $\mathrm{CH}, \mathrm{CON}+20 \mu \mathrm{M}$ ciglitazone. BSC, bovine satellite cells; DMEM, Dulbecco's modified Eagle's medium; HS, horse serum. 

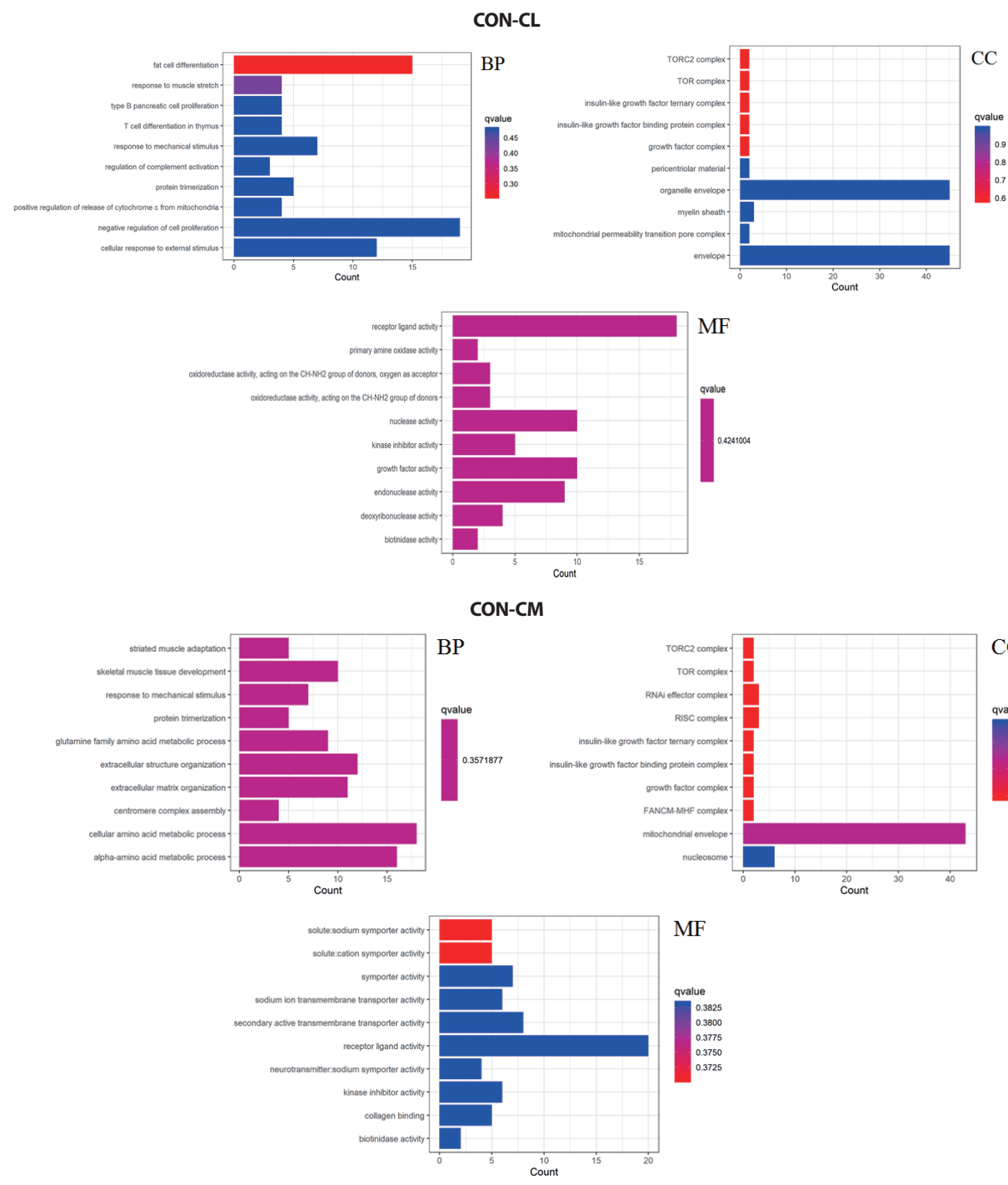

CON-CH
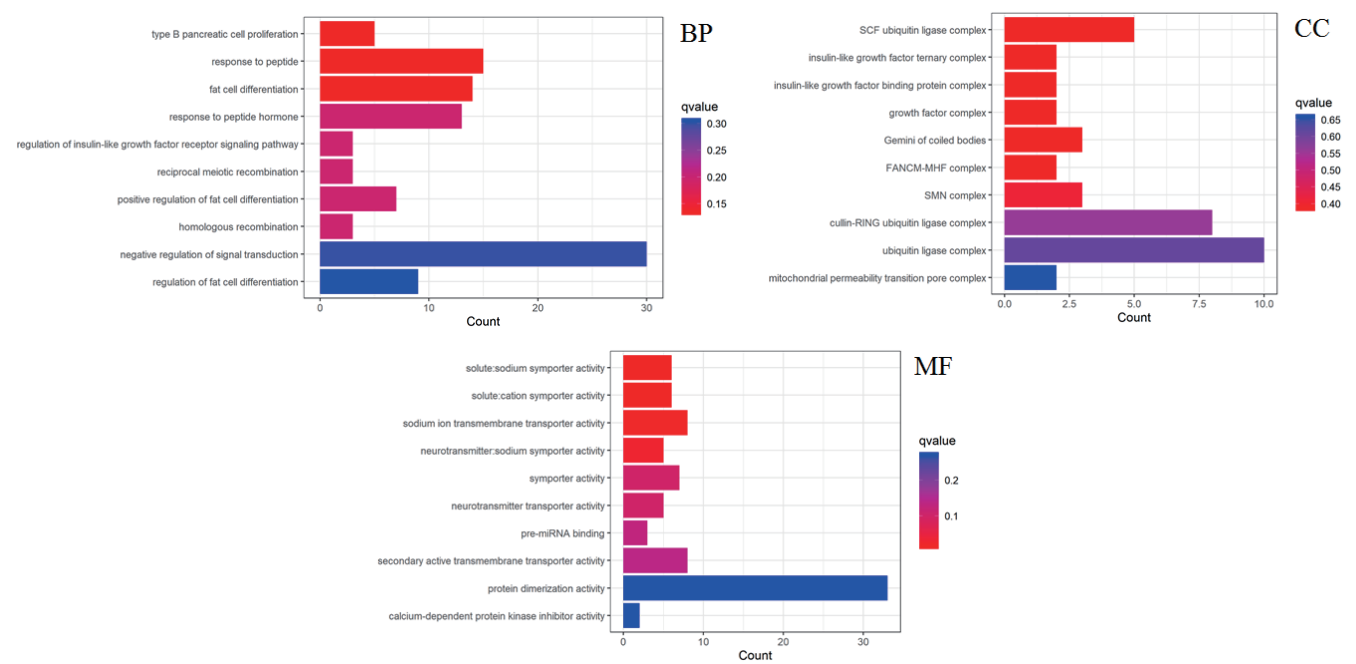

Fig. 10. Gene Ontology (GO) classification of differentially expressed genes (DEGs) after differentiation of BSC in Yanbian Yellow Cattle with different concentrations of ciglitazone. $\mathrm{CON}, \mathrm{DMEM}+2 \% \mathrm{HS} ; \mathrm{CL}, \mathrm{CON}+5 \mu \mathrm{M}$ ciglitazone; $\mathrm{CM}, \mathrm{CON}+10 \mu \mathrm{M}$ ciglitazone; $\mathrm{CH}, \mathrm{CON}+20 \mu \mathrm{M}$ ciglitazone. $\mathrm{BP}$, biological process; CC, cellular component; MF, molecular function; BSC, bovine satellite cells; DMEM, Dulbecco's modified Eagle's medium; HS, horse serum. 


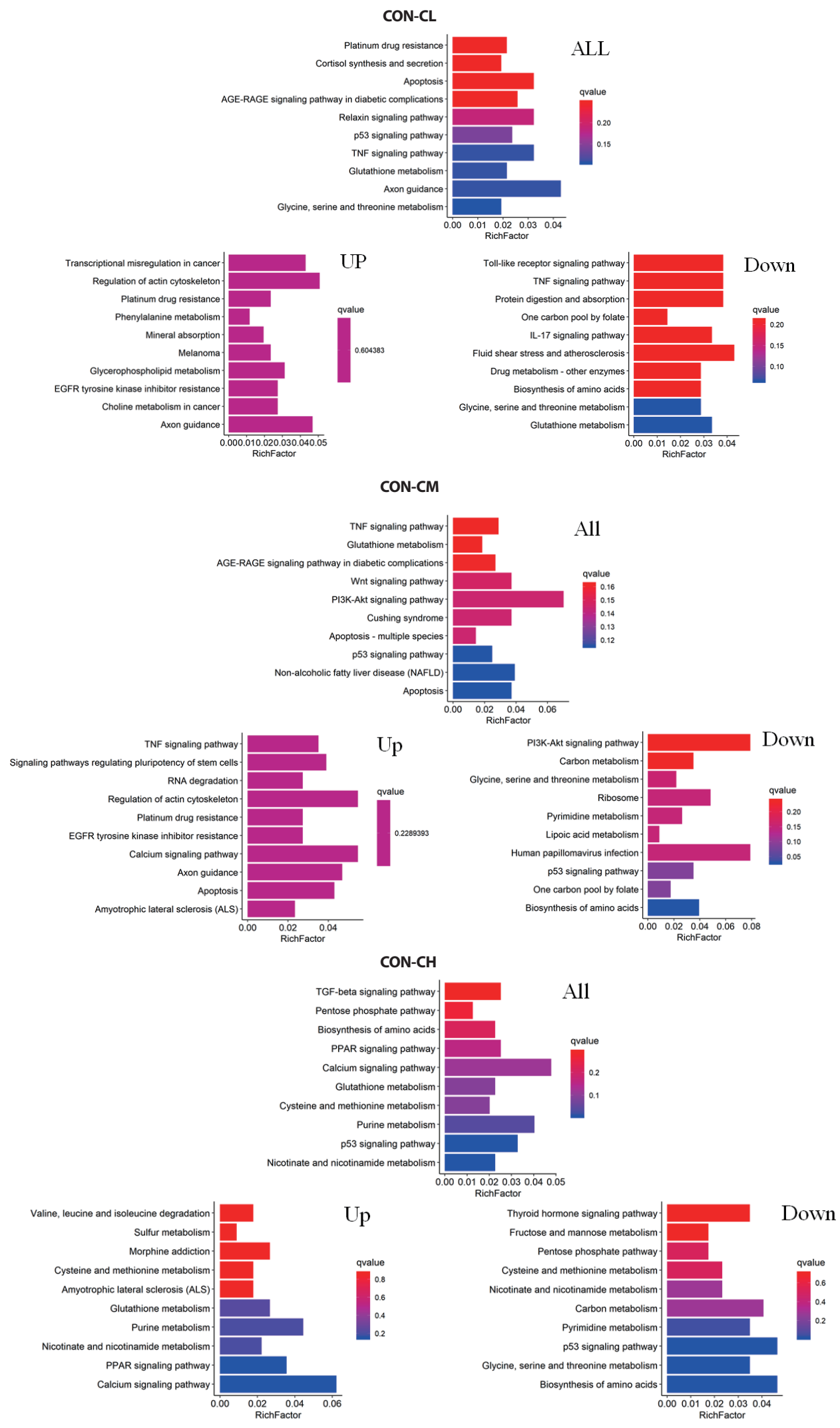

Fig. 11. KEGG functional enrichment of transcriptome from skeletal muscle satellite cells of different doses of ciglitazone. CON, DMEM $+2 \% H S$; CON-CL, CON + $5 \mu \mathrm{M}$ ciglitazone; CON-CM: CON + $10 \mu \mathrm{M}$ ciglitazone; CON-CH, CON + $20 \mu \mathrm{M}$ ciglitazone. KEGG, Kyoto Encyclopedia of Genes and Genomes; BSC, bovine satellite cells; DMEM, Dulbecco's modified Eagle's medium; HS, horse serum. 
mainly enriched in the calcium signaling pathway, PPAR signaling pathway, purine metabolism, nicotinate and nicotinamide metabolism, and genes with down-regulated expression were mainly enriched in the biosynthesis of amino acids p53 signaling pathway, glycine, serine, and threonine metabolism, pyrimidine metabolism, and carbon metabolism (Fig. 11 and Supplementary Table $\mathrm{S} 2)$.

Kyoto Encyclopedia of genes and genomes pathway enrichment analysis of differentially expressed genes

\section{Effects of increasing concentrations of ciglitazone on the pathway of prolifera- tor-activated receptor- $y$ enrichment}

As ciglitazone is a $P P A R \gamma$ agonist, we analyzed the $P P A R$-signaling pathway enriched by DEGs during adipogenic trans-differentiation of BSC induced by different concentrations of ciglitazone (Fig. 12). The high-concentration of ciglitazone significantly up-regulated the

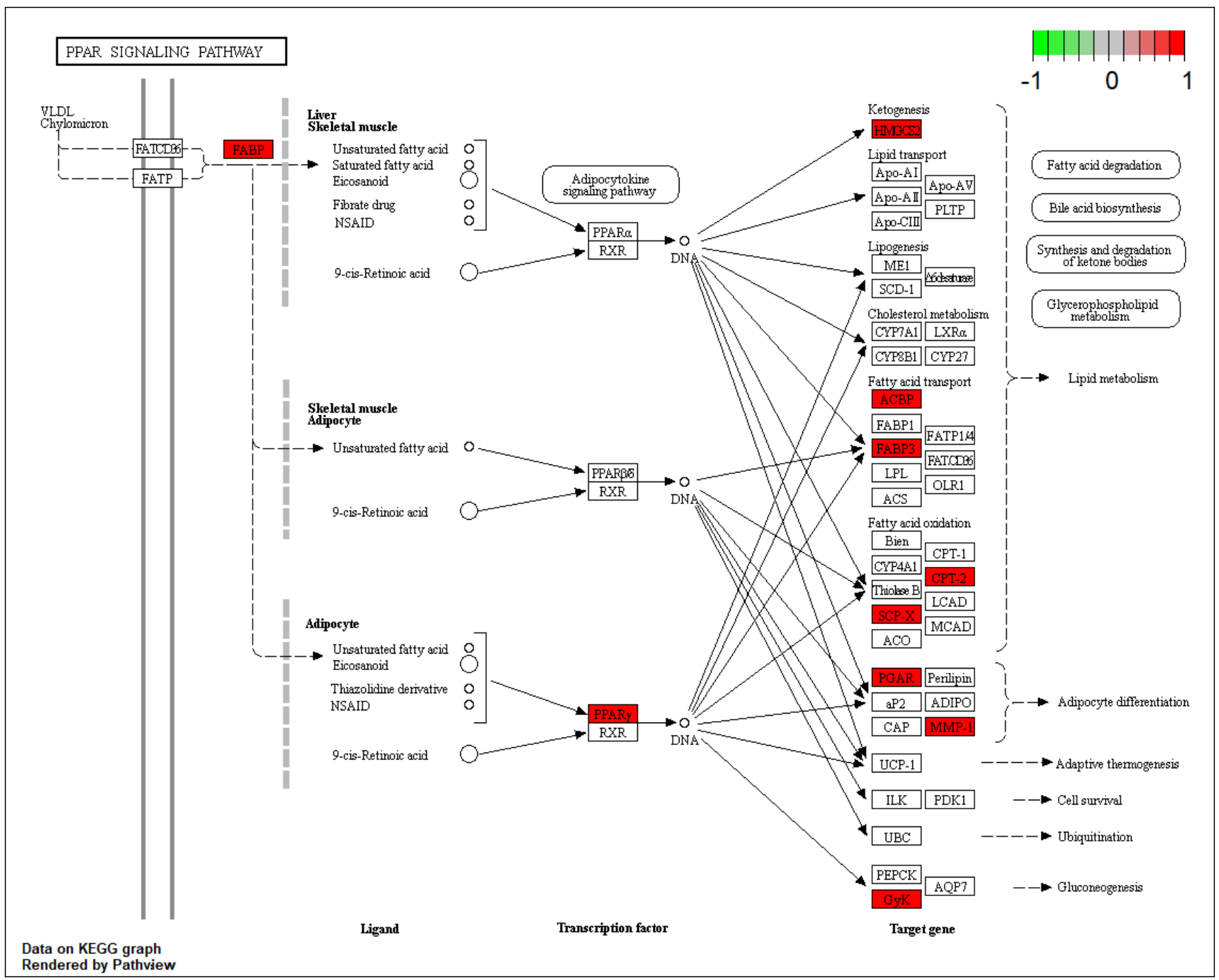

Fig. 12. PPAR signaling pathway regulated by high the concentration of ciglitazone. PPAR, proliferator-activated receptor. 


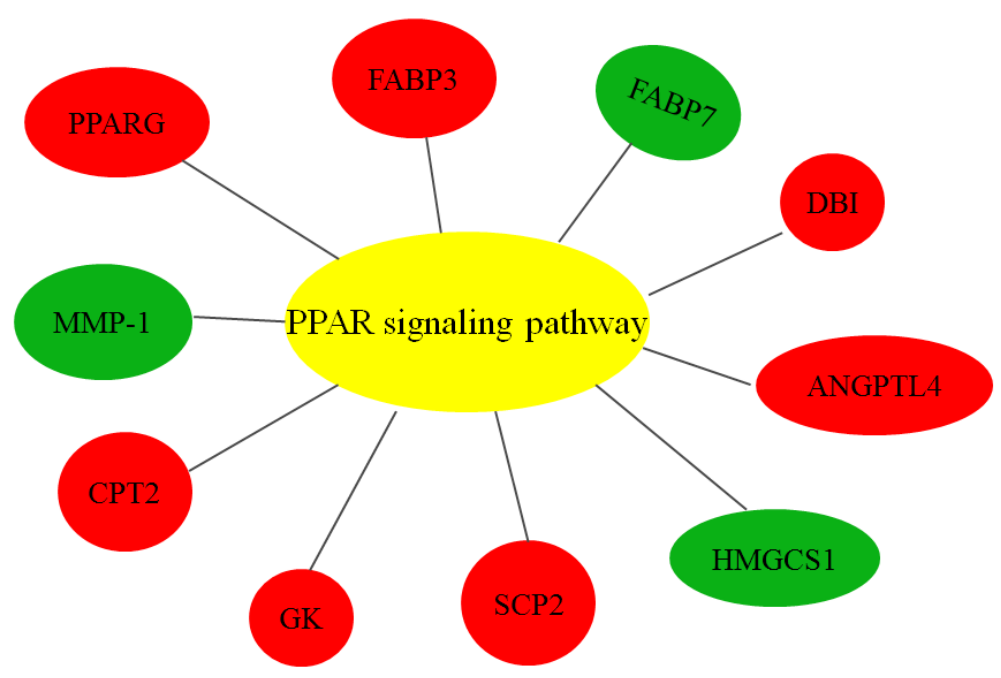

Fig. 13. Distribution of up and downregulated genes enrichment in different Kyoto Encyclopedia of Genes and Genomes (KEGG) pathways. Pathway nodes (yellow), up-regulated genes (red), and downregulated genes (green) are represented by circles. PPARG, peroxisome proliferator-activated receptor gamma; FABP4, fatty acid binding protein-4; FABP 7, fatty acid binding protein-7; DBI, diazepam binding inhibitor; ANGPTL4, angiopoietin like 4; HMGCS1, hydroxymethylglutaryl-CoA synthase; SCP-2, sterol carrier protein 2; GK; glycerolkinase; GPT2; alanine aminotransferase 2; MMP1; matrix metalloproteinase-1.

PPAR signaling pathway, there were 10 genes differentially enriched in this pathway, and the proportion of differentially enriched genes was 10/397. Pathway analysis of differentially enriched genes indicated 7 up-regulated genes and 3 down-regulated genes. Based on the up-regulated expression of $P P A R \gamma$, the downstream fatty acid transport-related genes (diazepam binding inhibitor [DBI], FABP3), fatty acid oxidation-related genes (CPT-2, sterol carrier protein 2, FABP3), adipocyte differentiation-related genes (angiopoietin like 4, glycogen neogenesis gene glucokinase), and the adipocyte differentiation-related gene $F A B P 7$ were up-regulated. The expression of matrix metalloproteinase-1 and the ketogenic gene hydroxymethylglutaryl-CoA synthase 2 was down-regulated (Fig. 13).

\section{DISCUSSION}

This study addressed the hypothesis that ciglitazone as a PPAR $\gamma$ ligand in the absence of an adipocyte differentiation cocktail would increase adiponectin and adipogenic gene expression in BSC. Previous studies investigated TZD as an extrinsic factor that influences myogenic satellite cells by inducing the expression of several transcription factors, including PPAR $\gamma$ and $C / E B P \alpha$ [7,8]. In cases where the conditions of the adipocytes containing the $P P A R \gamma$ activator permit, these cells can differentiate into mature adipocytes [9]. Li et al. [10] assumed that myoblasts and adipocytes have similar bio-initiating sources, and the potential for trans-differentiation to produce marbling or intramuscular lipogenesis was hypothesized. Transcriptional control of adipocyte differentiation requires a series of continuous gene expression events and activation of many key signaling pathways [11]. Cell lipid accumulation and morphological changes accompanying lipogenesis are caused by the induced expression of specific genes during differentiation [12]. In the present study, the decrease in the myotube formation and the increase in the accumulation of lipid droplets caused by ciglitazone addition in BSC. This may indicate that ciglitazone could induce the BSC to differentiate into adipocytes. 
Studies have reported that many transcription factors regulate adipocyte differentiation, such as C/EBPs and PPARs [9]. Muscle satellite cells can be trans-differentiated into mature adipocytes by ectopic expression of adipose trans-differentiation factors such as $P P A R \gamma$ [13]. Previous studies had documented that when the PPAR $\gamma$ gene was overexpressed in G8 myoblasts under optimal culture conditions for muscle differentiation, the expression levels of myogenic factors $M R F 5$, $M Y O D$, and MYF4 were depressed, and the myoblasts could not differentiate into myotubes [14]. In mammalian cells, $P P A R \gamma$ and $C / E B P \alpha$ are major regulators of lipogenesis and be transcription targets [15]. PPAR $\gamma$ is induced during the differentiation of preadipocytes into adipocytes, which is critical for precursor cells to differentiate into mature adipocytes [16]. Adipocyte differentiation also involves the expression of several other transcription factors that interact at different the process of adipogenesis to produce mature adipocytes [17]. Teboul et al. [4] demonstrated that TZDs specifically bind to and activate PPAR $\gamma$, increase the expression of $P P A R \gamma$ and related adipokines, and promote adipocyte differentiation. Kageyama et al. [18] demonstrated that pioglitazone increased body weight by selectively stimulating $P P A R \gamma$ and promoting lipid storage in white adipose tissue. Lizcano [19] reported that JMJD2C could inhibit PPAR $\gamma$ activity and reduce triglyceride accumulation in adipocytes. Although $P P A R \gamma$ and $C / E B P \alpha$ are highly synergistic in the adipogenic process, adipocyte genes vary in their reliance on $C / E B P \alpha$ and PPAR $\gamma$ [20].

$P a x 3$ and $P a x 7$ are markers of the differentiation of mesenchymal cells toward a myogenic cell lineage. Up-regulation of the expression of Pax3 and Pax7 increases the expression of myogenic regulatory factors [21], which include $M Y O D$ and MYOG. Up-regulation of MYOD expression promotes the conversion of somite-derived cells into myoblasts; $M Y O G$ is involved in the fusion of myoblasts to form myotubes [22]. Cornelison et al. [23] identified MYOD as a key negative regulator of brown adipocyte development. Similarly, Wang et al. [24] reported that MYOD negatively regulated the $\mathrm{f}$ brown adipocyte development and concluded that loss of MYOD facilitates adipogenic trans-differentiation of myoblasts in vivo. The PLIN2 is primarily expressed during the early stages of adipocyte differentiation, which promotes lipid droplet accumulation in muscle cells [25]. Studies with 3T3-L1 adipocytes indicated that PLIN2 could be used as a marker gene for precursors during adipocyte differentiation [26]. In this study, ciglitazone in the absence of an adipocyte differentiation cocktail also induced an up-regulation of adipogenic gene expression accompanied by low expression of MYOD, and the higher PLIN2 expression and adiponectin promotes the higher lipid droplets accumulation in the BSC [3].

Whole-genome RNA-Seq GO analysis and KEGG enrichment analysis of DEGs showed that most DEGs were closely related to cell proliferation, cell differentiation, and cell metabolic processes. PPAR signaling pathway, P53 signaling pathway, Wnt signaling pathway, ribosome, signaling pathway regulating pluripotency of stem cells, TNF signaling pathway, and calcium signaling pathway participate in the adipogenic transdifferentiation process of BSC. The high concentration of ciglitazone significantly up-regulated the PPAR signaling pathway, and 7 out of 10 genes were up-regulated in this pathway. Besides, the increase in the accumulation of lipid droplets and the concentration of $T A G$ and adiponectin further indicated the regulatory role of $P P A R \gamma$ in adipogenic transdifferentiation of BSC.

The PI3K-Akt signaling pathway plays an important regulatory role in adipocyte differentiation and adipogenesis. Inhibiting the activation of PI3K-Akt could depress adipogenesis and differentiation, and down-regulate the expression of adipogenic genes PPAR $\gamma, C / E B P a, F A B P 4$, and FATP1 [27,28]. Wnt signaling has been reported to inhibit adipogenesis. Adipose tissue contains adult stem cells (ADSCs) similar to mesenchymal stem cells, which inhibit adipogenic differentiation by activating the Wnt signaling pathway [29-31]. In this study, the RNA sequencing results revealed that the low concentration of ciglitazone could down-regulated the genes in the 
regulation of the Wnt signaling pathway, which revolved in adipogenesis and lipid metabolism.

TGF- $\beta 1$ is a factor activated by inflammation and participates in the process of chronic fibrosis of organs. TGF- $\beta 1$ transmits fibrotic signals through its downstream kinase substrate Smads protein. The TGF- $\beta 1 / \mathrm{Smad} 3$ signaling pathway and organ fibrosis are closely related. TGF- $\beta 1$ binds to its receptor on the cell membrane causes intracellular Smad2 and Smad3 phosphorylation and $S m a d 4$ binds to form a complex that enters the nucleus and cooperates with other transcription factors to regulate the expression of genes related to cell proliferation and differentiation [32-35]. In our study, the high concentration of ciglitazone can inhibit the activation of the TGF- $\beta 1 / \mathrm{Smad} 3$ signaling pathway. This may suggest that ciglitazone could promote the adipocyte phenotype in BSC through these signaling pathways. These results indicate that ciglitazone as a PPAR $\gamma$ agonist can promote lipid droplet formation and triglyceride accumulation in BSC, and effectively increase adiponectin concentration and adipogenic gene expression. RNS-seq showed that treatment with different concentrations of ciglitazone significantly affected the p53 signaling pathway, PPAR signaling pathway, TNF signaling pathway, PI3K-Akt signaling pathway, and Wnt signaling pathway.

In conclusion, our results support at least partial conversion of BSC to adipocytes by ciglitazone in the absence of an adipocyte differentiation cocktail. Further experiments are needed to elucidate the molecular mechanisms by which PPAR $\gamma$ affects lipogenesis during the process of adipogenic differentiation of BSC and the regulatory pathways that influence other regulators of lipid production.

\section{SUPPLEMENTARY MATERIALS}

Supplementary materials are only available online from: https://doi.org/ 10.5187/jast.2021.e87.

\section{REFERENCES}

1. Yeow K, Phillips B, Dani C, Cabane C, Amri EZ, Dérijard B. Inhibition of myogenesis enables adipogenic trans-differentiation in the C2C12 myogenic cell line. FEBS Lett. 2001;506:15762. https://doi.org/10.1016/S0014-5793(01)02900-3

2. Singh NK, Chae HS, Hwang IH, Yoo YM, Ahn CN, Lee SH, et al. Transdifferentiation of porcine satellite cells to adipoblasts with ciglitizone. J Anim Sci. 2007;85:1126-35. https://doi. org/10.2527/jas.2006-524

3. Li XZ, Yan Y, Zhang JF, Sun JF, Sun B, Yan CG, et al. Oleic acid in the absence of a PPAR $\gamma$ agonist increases adipogenic gene expression in bovine muscle satellite cells. J Anim Sci. 2019;97:4114-23. https://doi.org/10.1093/jas/skz269

4. Teboul L, Gaillard D, Staccini L, Inadera H, Amri EZ, Grimaldi PA. Thiazolidinediones and fatty acids convert myogenic cells into adipose-like cells. J Biol Chem. 1995;270:28183-7. https://doi.org/10.1074/jbc.270.47.28183

5. Chung KY, Lunt DK, Choi CB, Chae SH, Rhoades RD, Adams TH, et al. Lipid characteristics of subcutaneous adipose tissue and M. longissimus thoracis of Angus and Wagyu steers fed to US and Japanese endpoints. Meat Sci. 2006;73:432-41. https://doi.org/10.1016/j.meatsci.2006.01.002

6. Deutsch MJ, Schriever SC, Roscher AA, Ensenauer R. Digital image analysis approach for lipid droplet size quantitation of oil red O-stained cultured cells. Anal Biochem. 2014;445:879. https://doi.org/10.1016/j.ab.2013.10.001

7. Choi SH, Park SK, Johnson BJ, Chung KY, Choi CW, Kim KH, et al. AMPK $\alpha, \mathrm{C} / \mathrm{EBP} \beta$, 
CPT1 $\beta$, GPR43, PPAR $\gamma$, and SCD gene expression in single- and co-cultured bovine satellite cells and intramuscular preadipocytes treated with palmitic, stearic, oleic, and linoleic acid. Asian-Australas J Anim Sci. 2015;28:411-9. https://oi.org/10.5713/ajas.14.0598

8. Hu E, Tontonoz P, Spiegelman BM. Transdifferentiation of myoblasts by the adipogenic transcription factors PPAR gamma and C/EBP alpha. Proc Natl Acad Sci USA. 1995;92:9856-60. https://doi.org/10.1073/pnas.92.21.9856

9. Fux C, Mitta B, Kramer BP, Fussenegger M. Dual-regulated expression of C/EBP- $\alpha$ and BMP-2 enables differential differentiation of $\mathrm{C} 2 \mathrm{C} 12$ cells into adipocytes and osteoblasts. Nucleic Acids Res. 2004;32:e1. https://doi.org/10.1093/nar/gnh001

10. Li WC, Yu WY, Quinlan JM, Burke ZD, Tosh D. The molecular basis of transdifferentiation. J Cell Mol Med. 2005;9:569-82. https://doi.org/10.1111/j.1582-4934.2005.tb00489.x

11. Cheguru P, Chapalamadugu KC, Doumit ME, Murdoch GK, Hill RA. Adipocyte differentiation-specific gene transcriptional response to $\mathrm{C} 18$ unsaturated fatty acids plus insulin. Pflugers Arch Eur J Physiol. 2012;463:429-47. https://doi.org/10.1007/s00424-011-1066-7

12. Hassumi MY, Silva-Filho VJ, Campos-Júnior JC, Vieira SM, Cunha FQ, Alves PM, et al. PPARY agonist rosiglitazone prevents inflammatory periodontal bone loss by inhibiting osteoclastogenesis. Int Immunopharmacol. 2009;9:1150-8. https://doi.org/10.1016/j.intimp.2009.06.002

13. Yablonka-Reuveni Z, Day K, Vine A, Shefer G. Defining the transcriptional signature of skeletal muscle stem cells. J Anim Sci. 2008;86:E207-16. https://doi.org/10.2527/jas.2007-0473

14. Rehfeldt C, Kuhn G. Consequences of birth weight for postnatal growth performance and carcass quality in pigs as related to myogenesis. J Anim Sci. 2006;84. https://doi. org/10.2527/2006.8413_supple113x

15. Moseti D, Regassa A, Kim WK. Molecular regulation of adipogenesis and potential anti-adipogenic bioactive molecules. Int J Mol Sci. 2016;17:124. https://doi.org/10.3390/ijms17010124

16. Lefterova MI, Lazar MA. New developments in adipogenesis. Trends Endocrinol Metab. 2009;20:P107-14. https://doi.org/10.1016/j.tem.2008.11.005

17. Kim JB, Wright HM, Wright M, Spiegelman BM. ADD1/SREBP1 activates PPAR $\gamma$ through the production of endogenous ligand. Proc Natl Acad Sci USA. 1998;95:4333-7. https://doi.org/10.1073/pnas.95.8.4333

18. Kageyama H, Hirano T, Okada K, Ebara T, Kageyama A, Murakami T, et al. Lipoprotein lipase mRNA in white adipose tissue but not in skeletal muscle is increased by pioglitazone through PPAR- $\gamma$. Biochem Biophys Res Commun. 2003;305:22-7. https://doi.org/10.1016/s0006$291 \mathrm{x}(03) 00663-6$

19. Lizcano F, Romero C, Vargas D. Regulation of adipogenesis by nuclear receptor PPAR $\gamma$ is modulated by the histone demethylase JMJD2C. Genet Mol Biol. 2011;34:19-24. https://doi. org/10.1590/s1415-47572010005000105

20. Haakonsson AK, Stahl Madsen M, Nielsen R, Sandelin A, Mandrup S. Acute genome-wide effects of rosiglitazone on PPAR $\gamma$ transcriptional networks in adipocytes. Mol Endocrinol. 2013;27:1536-49. https://doi.org/10.1210/me.2013-1080

21. Cossu G, Borello U. Wnt signaling and the activation of myogenesis in mammals. EMBO J. 1999;18:6867-72. https://doi.org/10.1093/emboj/18.24.6867

22. Stewart CEH, Rittweger J. Adaptive processes in skeletal muscle: molecular regulators and genetic influences. J Musculoskelet Neuronal Interact. 2006;6:73-86.

23. Cornelison DDW, Olwin BB, Rudnicki MA, Wold BJ. MyoD-/- satellite cells in single-fiber culture are differentiation defective and MRF4 deficient. Dev Biol. 2000;224:122-37. https:// doi.org/10.1006/dbio.2000.9682 
24. Wang C, Liu W, Nie Y, Qaher M, Horton HE, Yue F, et al. Loss of MyoD promotes fate transdifferentiation of myoblasts into brown adipocytes. EBioMedicine. 2017;16:212-23. https://doi.org/10.1016/j.ebiom.2017.01.015

25. Minnaard R, Schrauwen P, Schaart G, Jorgensen JA, Lenaers E, Mensink M, et al. Adipocyte differentiation-related protein and OXPAT in rat and human skeletal muscle: involvement in lipid accumulation and type 2 diabetes mellitus. J Clin Endocrinol Metab. 2009;94:4077-85. https://doi.org/10.1210/jc.2009-0352

26. Dodson MV, Wei S, Duarte M, Du M, Jiang Z, Hausman GJ, et al. Cell supermarket: adipose tissue as a source of stem cells.J Genomics. 2013;1:39-44. https://doi.org/10.7150/jgen.3949

27. Yi X, Liu J, Wu P, Gong Y, Xu X, Li W. The whole transcriptional profiling of cellular metabolism during adipogenesis from hMSCs. J Cell Physiol. 2020;235:349-63. https://doi. org/10.1002/jcp.28974

28. Barthel A, Okino ST, Liao J, Nakatani K, Li J, Whitlock JP Jr, et al. Regulation of GLUT1 gene transcription by the serine/threonine kinase Akt1. J Biol Chem. 1999;274:20281-6. https://doi.org/10.1074/jbc.274.29.20281

29. Ross SE, Hemati N, Longo KA, Bennett CN, Lucas PC, Erickson RL, et al. Inhibition of adipogenesis by Wnt signaling. Science. 2000;289:950-3. https://doi.org/10.1126/science.289.5481.950

30. Kang S, Bajnok L, Longo KA, Petersen RK, Hansen JB, Kristiansen K, et al. Effects of Wnt signaling on brown adipocyte differentiation and metabolism mediated by PGC- $1 \alpha$. Mol Cell Biol. 2005;25:1272-82. https://doi.org/10.1128/mcb.25.4.1272-1282.2005

31. Prestwich TC, Macdougald OA. Wnt/ $\beta$-catenin signaling in adipogenesis and metabolism. Curr Opin Cell Biol. 2007;19:612-7. https://doi.org/10.1016/j.ceb.2007.09.014

32. Budi EH, Duan D, Derynck R. Transforming growth factor- $\beta$ receptors and Smads: regulatory complexity and functional versatility. Trends Cell Biol. 2017;27:658-72. https://doi. org/10.1016/j.tcb.2017.04.005

33. Kang JS, Liu C, Derynck R. New regulatory mechanisms of TGF- $\beta$ receptor function. Trends Cell Biol. 2009;19:385-94. https://doi.org/10.1016/j.tcb.2009.05.008

34. Fabregat A, Jupe S, Matthews L, Sidiropoulos K, Gillespie M, Garapati P, et al. The reactome pathway knowledgebase. Nucleic Acids Res. 2018;46:D649-55. https://doi.org/10.1093/nar/ gkx1132

35. Yue Y, Meng K, Pu Y, Zhang X. Transforming growth factor beta (TGF- $\beta$ ) mediates cardiac fibrosis and induces diabetic cardiomyopathy. Diabetes Res Clin Pract. 2017;133:124-30. https://doi.org/10.1016/j.diabres.2017.08.018 